\title{
PENGARUH PEMBELAJARAN ORGANISASI, KEPUASAN KERJA DAN ORIENTASI PASAR TERHADAP KINERJA MANAJER DAN KINERJA UNIT BISNIS (Studi Pada Koperasi Pengelola Susu Sapi Perah Di Jawa Timur)
}

\author{
Oleh \\ Salim Al Idrus*)
}

Penelitian ini bertujuan untuk (1) menjelaskan pengaruh pembelajaran organisasi terhadap kinerja manajer, (2) kepuasan kerja terhadap kinerja manajer, (3) orientasi pasar terhadap kinerja manajer, (4) pembelajaran organisasi terhadap kinerja unit bisnis, (5) kepuasan kerja terhadap kinerja unit bisnis, (6) orientasi pasar terhadap kinerja unit bisnis dan (7) kinerja manajer terhadap kinerja unit bisnis.

Penelitian ini dirancang dengan menggunakan pendekatan kuantitatif dan hubungan kausal antar variabel penelitian yang dikemas dalam analisis jalur (path analysis). Penelitian ini dilakukan pada koperasi pengelola susu sapi perah di Jawa Timur dengan sampel 33 koperasi. Sampel diambil dengan menggunakan simple random sampling. Data penelitian diambil melalui kuesioner. Pernyataan yang dikembangkan melalui instrumen diproses dengan menggunakan software SPSS versi 13.0.

Temuan hasil penelitian mengungkapkan bahwa semakin tinggi pembelajaran organisasi, kepuasan kerja, dan orientasi pasar, maka semakin tinggi pula kinerja unit bisnis yang dihasilkan. Sedangkan pada variabel kinerja manajer, semakin tinggi kinerja yang dilakukan manajer dapat menurunkan kinerja unit bisnis koperasi.

Kata kunci: Pembelajaran Organisasi, Kepuasan Kerja, Orientasi Pasar, Kinerja Manajer, dan Kinerja Unit Bisnis Sapi Perah

\section{PENDAHULUAN}

\section{Latar Belakang}

Pada saat ini, kondisi koperasi pada umumnya masih lemah, baik kondisi internal yang berupa permodalan, manajemen, organisasi, dan teknologi serta jaringan usaha maupun kondisi eksternal yang disebabkan oleh lingkungan strategis seperti penguasaan pasar, berbagai sumber dan kegiatan ekonomi (Prawirokusumo, 2001).

Dalam kondisi yang demikian, sangat sulit bagi koperasi untuk dapat tumbuh dan berkembang dalam upaya mewujudkan fungsi dan perannya dengan baik, apalagi jika dihadapkan pada kondisi ekonomi saat ini yang 
mengarah kepada mekanisme pasar dan persaingan bebas sebagai konsekwensi kecenderungan tuntutan dalam era globalisasi.

Dengan semakin ketatnya persaingan bisnis tentu saja semakin banyak pula transaksi-transaksi yang terjadi. Dengan demikian semakin besar pula volume pekerjaan yang harus ditangani dan juga masalah yang dihadapi, untuk itu koperasi dituntut untuk mengelola usahanya secara lebih profesional.

Keberhasilan perusahaan untuk mencapai kinerja pasar secara terus menerus ditentukan oleh sejauhmana perusahaan mampu menciptakan keunggulan bersaing yang berkelanjutan (Aaker, 1989). Perusahaan yang mampu memberikan produk dan jasa yang superior kepada pelanggan akan dapat bersaing di lingkungan tersebut. Pemberian nilai yang superior kepada pelanggan dapat dilakukan melalui kualitas produk atau jasa yang superior sesuai dengan kebutuhan dan keinginan pelanggan (Menon, Jaworski, Kohli, 1997; Johnson, 1998:10).

Harapan untuk memberikan nilai yang superior bagi pelanggan dapat diwujudkan melalui usaha menciptakan dan memelihara budaya yang mampu menghasilkan perilaku yang diperlukan ke arah tersebut (Narver dan Slater, 1990). Orientasi pasar (market orientation) dan pembelajaran organisasi adalah budaya organisasi yang paling efektif dan efisien dalam membentuk perilaku guna menciptakan nilai yang superior bagi pembeli dan kinerja superior secara berkelanjutan bagi bisnis (Kohli dan Jaworski, 1990).

Orientasi pasar sangat bernilai karena akan memfokuskan organisasi pada usaha pengumpulan informasi secara terus menerus mengenai kebutuhan pelanggan dan kapabilitas pesaing. Informasi yang telah terkumpul tersebut akan digunakan sebagai bahan pertimbangan dalam menciptakan nilai bagi pelanggannya (Slater dan Narver, 1995).

Perusahaan yang berorientasi pasar akan dapat mengantisipasi dan responsif terhadap apa yang dibutuhkan pelanggannya saat ini dan masa yang akan datang. Orientasi pasar merupakan konsep yang lebih luas yang tidak hanya mencakup orientasi pada pelanggan (customer orientation) tetapi juga orientasi kepada pesaing dan aktivitas yang melibatkan koordinasi antar fungsi dalam perusahaan (Narver dan Slater, 1990; Voss dan Voss, 2000). Perusahaan yang berorientasi pasar secara formal akan melakukan aktivitas menghasilkan 
intelijensi pasar serta menyebarkan hasil intelijensi ke seluruh departemen dan tanggap untuk menindaklanjuti apa yang dibutuhkan dan diharapkan konsumen (Kohli dan Jaworski, 1990; Baker dan Sinkula, 1999).

Meskipun orientasi pasar dipandang penting, namun beberapa masalah mendasar tentang hal tersebut belum menjadi tujuan penelitian empiris hingga saat ini (Jaworski dan Kohli, 1993). Masih sedikit riset yang memfokuskan orientasi pasar sebagai subyek penelitian dan beberapa studi yang dilakukan lebih tertarik mengkaji pada seberapa jauh organisasi berorientasi pasar daripada meneliti faktor yang mempengaruhi maupun konsekuensinya (Jaworski dan Kohli, 1993).

Salah satu budaya organisasi yang terkait dengan orientasi pasar adalah pembelajaran organisasi. Bagi suatu perusahaan meningkatnya keyakinan dan aktivitas perilaku yang berpembelajaran organisasi adalah penting terutama dalam pembentukan perilaku adaptif dalam menghadapi perubahan lingkungan yang penuh dengan ketidakpastian. Di dalam organisasi yang berpembelajaran organisasi akan berkembang pengetahuan baru dan pemahaman baru yang secara potensial akan mempengaruhi perilaku. Anggota organisasi akan berbagi informasi, menciptakan organizational memory dalam bentuk keyakinan, asumsi dan norma bersama (Sinkula, 1994). Aktivitas pengorganisasian, kreativitas, kecakapan dan transfer pengetahuan akan terjadi yang selanjutnya diharapkan mampu memperbaiki perilaku sebagai perwujudan wawasan dan pengetahuan baru (Garvin, 1993). Oleh karena itu, pembelajaran organisasi penting untuk mencapai sasaran dan perbaikan kinerja (Slater dan Narver, 1995). Dalam penelitian yang dilakukan Sinkula, Baker dan Noordewier (1997) dinyatakan bahwa pembelajaran organisasi akan berpengaruh pada perilaku pemrosesan informasi dan perilaku lain yang terjadi pada perusahaan yang berorientasi pasar.

Perilaku atau aktivitas yang terjadi pada perusahaan yang berorientasi pasar dan berpembelajaran organisasi akan mengarah pada peningkatan kinerja dan keunggulan bersaing. Penelitian yang dilakukan Narver dan Slater (1990) menunjukkan bahwa orientasi pasar, faktor karakteristik khusus bisnis dan faktor lingkungan berpengaruh terhadap kinerja bisnis. Penelitian yang dilakukan Jaworski dan Kohli (1993) serta Horng dan Chen (1998) juga 
menunjukkan orientasi pasar berpengaruh terhadap kinerja bisnis. Penelitian serupa yang dilakukan pada perusahaan manufaktur skala kecil dan menengah yang dilakukan Pelham dan Wilson (1996) juga memperlihatkan bahwa orientasi pasar berpengaruh terhadap kinerja bisnis.

Orientasi pasar dan pembelajaran organisasi merupakan budaya yang mengarahkan anggota organisasi melakukan sikap-sikap tertentu untuk menyesuaikan perubahan-perubahan yang berlangsung di dalam organisasi dan lingkungan.

Kepuasan kerja karyawan yang dikaji oleh Luthans (1995:126) berhubungan dengan bentuk sikap yang diekspresikan oleh karyawan dalam menghadapi pekerjaannya.

Menurut Schwab dan Cummings (1970), faktor utama yang dipandang sebagai sumber potensial pemicu kepuasan atau ketidakpuasan kerja antara lain: supervisi, kondisi kerja, kebijakan perusahaan, dan manfaat yang dirasakan. Review Schwab dan Cummings (1970) terhadap beberapa studi mengenai hubungan kepuasan kerja dan kinerja menyimpulkan bahwa kepuasan kerja dapat mempengaruhi kinerja atau justru kepuasan kerja dipengaruhi oleh kinerja. Selanjutnya Schwab dan Cummings (1970) juga menyatakan bahwa kinerja akan mempengaruhi kepuasan kerja jika dengan kinerja, bawahan akan mendapatkan reward instrinsik (promosi) maupun ekstrinsik (gaji, bonus).

Dalam penelitian Wiley and Sons (1998:149) dinyatakan bahwa kepuasan kerja mempengaruhi kinerja dalam arti untuk meningkatkan kinerja manajer terlebih dahulu harus membuatnya bahagia (enjoy) lalu diharapkan akan mengarah pada profesionalisasi kerja ke depan, selain juga memperhatikan hakhaknya.

Churchill et al. (1985) memberi argumentasi bahwa kepuasan kerja mempunyai hubungan dengan kinerja karyawan dalam hubungannya dengan penjualan. Hubungan ini terletak pada interaksi antara karyawan dengan pelanggan, dimana karyawan yang merasa puas mempunyai perilaku untuk membantu pelanggan (Locke dan Luthan, 1990). Riset lain yang dilakukan oleh Schneider (1990) menemukan bukti bahwa karyawan yang mengalami konflik peran memiliki kecenderungan kepuasan kerja dan kinerja yang rendah. 
Faktor lain yang juga berperan penting dalam situasi persaingan bisnis adalah produktivitas tenaga kerja. Menurut Anonim (dalam A Report ForTrade Partners, UK, 2000) tentang "Exporting Business Performances", menyebutkan bahwa labour productivity (produktivitas tenaga kerja) berpengaruh signifikan dengan tingkat pertumbuhan ekspor.

Selanjutnya dikatakan oleh penelitinya : jika tenaga kerja dibayar dengan tambahan marjinal produk (marginal product) yang dilakukan selain upah, akan berpengaruh positif dengan total factor productivity (produktivitas total) yang tentunya juga berpengaruh positif pada eksporting itu sendiri.

Bagi lembaga koperasi adanya budaya orientasi pasar dan pembelajaran organisasi merupakan hal yang penting di tengah situasi persaingan yang demikian intensif. Oleh karena itu upaya yang mengarah pada berkembangnya kedua unsur budaya tersebut sangat diperlukan sebagai sumber keunggulan bersaing. Diharapkan dengan adanya kedua budaya tersebut perusahaan memiliki kinerja bisnis yang unggul untuk jangka pendek dan juga untuk jangka panjang.

\section{METODE}

Penelitian ini dirancang dengan menggunakan pendekatan kuantitatif dan hubungan kausal antar variabel penelitian yang dikemas dalam analisis jalur (path analysis). Penelitian ini dilakukan pada koperasi pengelola susu sapi perah di Jawa Timur dengan sampel 33 koperasi. Sampel diambil dengan menggunakan simple random sampling. Data penelitian diambil melalui kuesioner. Pernyataan yang dikembangkan melalui instrumen diproses dengan menggunakan software SPSS versi 13.0.

Analisis data dan pengujian hipotesis dilakukan dengan (a) analisis deskriptif yaitu untuk mendapatkan penyebaran hasil penelitian dari masingmasing variabel sehingga tergambar respon responden dengan metode descriptive statistic method frequencies; dan (b) analisis jalur (path analysis) dengan uji persyaratan analisis jalur dimana hubungan antar variabel bebas dan variabel terikat. Kemudian untuk membuktikan hipotesis digunakan analisis 
regresi bertahap dengan persyaratan asumsi klasik yaitu: linieritas, normalitas, multikolinieritas, heteroskedastisitas, dan autokorelasi.

Pengoperasian analisis jalur menggunakan analisis regresi berganda secara bertingkat, satu persamaan demi satu persamaan. Pada penelitian ini dibagi menjadi dua persamaan, yaitu:

1. Persamaan pertama yaitu regresi antara $X_{1}, X_{2}$, dan $X_{3}$ terhadap $X_{4}$, dimana $X_{4}$ sebagai variabel terikat.

2. Persamaan kedua yaitu regresi antara $X_{1}, X_{2}, X_{3}$, dan $X_{4}$ terhadap $Y$, dimana $Y$ sebagai variabel terikat.

Dalam hal ini setiap persamaan analisis akan menimbulkan suatu persamaan regresi. Karena pada analisis ini meliputi 2 persamaan maka akan mempunyai 2 persamaan regresi. Secara umum persamaan tersebut adalah:

$$
\hat{Y}=a_{0}+b_{1} X_{1}+b_{2} X_{2}+\ldots+b_{k} X_{k}
$$

Keterangan:

$\hat{Y}=$ Nilai $Y$ yang diprediksi/diduga.

$\mathrm{X}=$ variabel bebas.

$\mathrm{a}=$ intercept (konstanta), yaitu nilai $\mathrm{Y}$ jika semua nilai $\mathrm{X}$ sama dengan nol.

$\mathrm{b}=$ slope (koefisien regresi), yaitu bilangan yang menunjukkan berapa nilai $\mathrm{Y}$ naik/turun apabila nilai $X$ tertentu naik/turun satu satuan.

$\mathrm{k}=$ Jumlah variabel bebas yang ada dalam model.

Untuk membuktikan hipotesis penelitian, maka dilakukan analisis secara keseluruhan dari persamaan pertama sampai persamaan kedua. Untuk menguji signifikansi pengaruh parsial independent variabel terhadap dependent variabel dirumuskan hipotesis:

$$
\mathrm{H}_{0}: \beta_{1}=0
$$

Berarti independent variabel $(\mathrm{X})$ tidak mempunyai pengaruh signifikan terhadap dependent variabel $(\mathrm{Y})$.

$$
\mathrm{H}_{1}: \beta_{1} \neq 0
$$

Berarti independent variabel $(X)$ mempunyai pengaruh signifikan terhadap dependen variabel $(Y)$. 
HASIL

Berdasarkan analisis deskriptif untuk mendapatkan penyebaran hasil penelitian dari masing-masing variabel, maka dapat dijelaskan bahwa kesetujuan pentingnya pembelajaran organisasi diperoleh: sangat tidak setuju $0 \%$, tidak setuju $0 \%$, kurang setuju 3\%, cukup setuju $21 \%$, setuju $46 \%$ dan sangat setuju $30 \%$. Untuk intensitas kepuasan kerja diperoleh tidak memuaskan $0 \%$, kurang memuaskan $21 \%$, cukup memuaskan $27 \%$, memuaskan $46 \%$ dan sangat memuaskan $6 \%$. Untuk intensitas untuk melakukan orientasi pasar diperoleh sangat jarang $0 \%$, jarang $3 \%$, kadang-kadang $6 \%$, cukup sering $33 \%$, sering $55 \%$ dan sangat sering 3\%. Untuk intensitas kinerja manajer diperoleh sangat jarang $0 \%$, jarang $0 \%$, kadang-kadang $6 \%$, cukup sering 30\%, sering 55\% dan sangat sering 9\%. Sedangkan untuk kinerja unit bisnis diperoleh jelek 30\%, sangat jelek $55 \%$, cukup jelek $3 \%$, cukup baik $6 \%$, baik $3 \%$ dan sangat baik $0 \%$.

Sedangkan hasil penelitian setelah diadakan pengujian hipotesis adalah sebagai tabel berikut:

Tabel 1. Hasil Penelitian

\begin{tabular}{|c|c|l|c|c|c|c|}
\hline No & $\mathbf{H}$ & \multicolumn{1}{|c|}{ Hipotesis } & $\begin{array}{c}\mathbf{t}_{\text {hitung }} \\
\mathbf{t}_{\text {tabel }}\end{array}$ & $\begin{array}{c}\text { Signifi- } \\
\mathbf{k a n s i}\end{array}$ & Keterangan & Kesimpulan \\
\hline 1 & $\mathrm{H} 1$ & $\begin{array}{l}\text { Pembelajaran } \\
\text { organisasi } \\
\text { berpengaruh terhadap } \\
\text { kinerja manajer }\end{array}$ & 1.386 & 0.176 & $\begin{array}{c}\text { Tidak } \\
\text { signifikan }\end{array}$ & $\begin{array}{c}\text { Tidak } \\
\text { terbukti (H1 } \\
\text { ditolak) }\end{array}$ \\
\hline 2 & H & $\begin{array}{l}\text { Kepuasan kerja } \\
\text { berpengaruh terhadap } \\
\text { kinerja manajer }\end{array}$ & 0.504 & 0.618 & $\begin{array}{c}\text { Tidak } \\
\text { signifikan }\end{array}$ & $\begin{array}{c}\text { Tidak } \\
\text { terbukti (H2 } \\
\text { ditolak) }\end{array}$ \\
\hline 3 & H3 & $\begin{array}{l}\text { Orientasi pasar } \\
\text { berpengaruh terhadap } \\
\text { kinerja manajer }\end{array}$ & 3.081 & 0.004 & Signifikan & $\begin{array}{c}\text { Terbukti } \\
\text { (H3 tidak } \\
\text { ditolak) }\end{array}$ \\
\hline H4 & $\begin{array}{l}\text { Pembelajaran } \\
\text { organisasi } \\
\text { berpengaruh terhadap } \\
\text { kinerja unit bisnis }\end{array}$ & 0.257 & 0.799 & Tidak & $\begin{array}{c}\text { Tidak } \\
\text { terbukti (H4 } \\
\text { ditolak) }\end{array}$ \\
\hline
\end{tabular}




\begin{tabular}{|c|c|l|c|c|c|c|}
\hline 5 & H5 & $\begin{array}{l}\text { Kepuasan kerja } \\
\text { berpengaruh terhadap } \\
\text { kinerja unit bisnis }\end{array}$ & 1.28 & 0.211 & $\begin{array}{c}\text { Tidak } \\
\text { signifikan }\end{array}$ & $\begin{array}{c}\text { Tidak } \\
\text { terbukti (H5 } \\
\text { ditolak) }\end{array}$ \\
\hline 6 & H6 & $\begin{array}{l}\text { Orientasi pasar } \\
\text { berpengaruh terhadap } \\
\text { kinerja unit bisnis }\end{array}$ & 1.237 & 0.226 & $\begin{array}{c}\text { Tidak } \\
\text { signifikan }\end{array}$ & $\begin{array}{c}\text { Tidak } \\
\text { terbukti (H6 } \\
\text { ditolak) }\end{array}$ \\
\hline 7 & H7 & $\begin{array}{l}\text { Kinerja manajer } \\
\text { berpengaruh terhadap } \\
\text { kinerja unit bisnis }\end{array}$ & -0.642 & 0.526 & $\begin{array}{c}\text { Tidak } \\
\text { signifikan }\end{array}$ & $\begin{array}{c}\text { Tidak } \\
\text { terbukti (H7 } \\
\text { ditolak) }\end{array}$ \\
\hline
\end{tabular}

Keterangan: Signifikansi pada level 5\% 
PEMBAHASAN

Hasil pengujian hipotesis dalam penelitian ini, masing-masing akan dibahas sebagai berikut:

\section{Pengaruh Pembelajaran Organisasi terhadap Kinerja Manajer}

Tidak terdapat pengaruh yang signifikan pada variabel pembelajaran organisasi terhadap kinerja manajer pada koperasi pengelola susu sapi perah di Jawa Timur, dimana menunjukkan hasil uji hipotesis untuk pembelajaran organisasi ini tidak sejalan dengan Luthans (1995) bahwa pembelajaran organisasi merupakan kesempatan yang diberikan manajer kepada pegawai sehingga kinerjanya menjadi lebih efisien.

Dalam penelitian ini, pembelajaran organisasi tidak berpengaruh signifikan terhadap kinerja manajer. Hal ini terjadi adanya kecenderungan para manajer belum merasa penting untuk mengetahui dan mengaplikasikan proses pembelajaran organisasi secara maksimal untuk meningkatkan kinerjanya pada koperasi pengelola susu sapi perah di Jawa Timur (Suwasono, 2006). Fenomena ini terjadi sesuai dengan data yang diperoleh di lapangan dari indikatorindikator yang diberikan untuk mengukur pembelajaran organisasi pada koperasi pengelola susu sapi perah di Jawa Timur.

Demikian juga yang disampaikan oleh Suwasono selaku pengurus GKSI pada RK dan RAPB GKSI di Koperasi SAE Pujon Malang pada pertengahan Mei tahun 2006 bahwa komitmen berorganisasi pada GKSI Jawa Timur masih lemah terhadap ketentuan-ketentuan yang telah disepakati bersama.

Demikian juga disampaikan oleh Sudjono (2000) tahun 2000 dimana dalam pembelajaran perkoperasian bahwa pendekatan-pendekatan tuntas dengan menerapkan konsep yang salah terutama menjadikan koperasi kepanjangan tangan pemerintah sehingga kehilangan jatidirinya sebagai lembaga otonom haruslah ditinggalkan. Lebih lanjut dikatakan juga olehnya dalam pembelajaran perkoperasian bukanlah menggunakan pendekatan dari atas ke bawah (top down) melainkan menggunakan dari bawah ke atas (bottom up) agar lebih membumi.

\section{Pengaruh Kepuasan Kerja terhadap Kinerja Manajer}


Tidak terdapat pengaruh yang signifikan pada variabel kepuasan kerja terhadap kinerja manajer pada koperasi pengelola susu sapi perah di Jawa Timur. Hal ini terjadi dimana penciptaan iklim yang kondusif oleh pengurus dan tanggapan secara positif dan proaktif oleh manajer masih bersifat problematik pada koperasi pengelola susu sapi perah di Jawa Timur (Nirbito, 2003).

Hasil uji hipotesis kepuasan kerja ini tidak sejalan dengan (a) Churchill et al. (1985) bahwa kepuasan kerja mempunyai hubungan dengan kinerja manajer/karyawan dalam hubungannya dengan penjualan, (b) Schneider (1990) menemukan bukti bahwa manajer/karyawan yang mengalami konflik peran memiliki kecenderungan kepuasan kerja dan kinerja yang rendah, (c) Chummings (1970) bahwa kepuasan kerja dapat mempengaruhi kinerja atau justru kepuasan kerja dipengaruhi oleh kinerja, (d) Schwab dan Chummings (1970) bahwa kinerja akan mempengaruhi kepuasan kerja jika mendapatkan reward intrinsik (promosi) maupun ekstrinsik (gaji, bonus).

Demikian juga disampaikan oleh Suwasono (2006) dimana agar pelaksanaan konsolidasi anggota koperasi pengelola susu sapi perah di Jawa Timur untuk lebih ditanggapi atau direspon. Artinya anggota Koperasi Susu Perah GKSI masih belum menanggapi atau merespon untuk lebih berkonsolidasi di antara sesama anggota.

Demikian pula dikatakan Nirbito (2005) bahwa untuk memperoleh kenyamanan di dalam pelaksanaan perkoperasian bukanlah melalui intruksiintruksi atau perintah-perintah yang kaku melainkan penggunaan kearifan melalui pemberian dorongan atau fasilitas agar koperasi berkembang secara mandiri dan dapat berperan secara nyata bagi anggota dan masyarakatnya.

\section{Pengaruh Orientasi Pasar terhadap Kinerja Manajer}

Terdapat pengaruh yang signifikan pada variabel orientasi pasar terhadap kinerja manajer pada koperasi pengelola susu sapi perah di Jawa Timur. Hal ini terjadi karena adanya tuntutan pemasaran susu dengan kualitas yang lebih baik serta syarat-syarat yang ketat dari industri pengolahan susu (PT. Nestle Jawa Timur) yang memacu para manajer lebih bekerja keras mensukseskan pemasaran susu tersebut secara kontinyu (Suwasono, 2006). 
Hasil uji hipotesis variabel orientasi pasar berpengaruh signifikan terhadap kinerja manajer sejalan dengan yang dikemukakan oleh Naver dan Slater (1990) bahwa orientasi pasar merupakan filosofi bisnis yang dipandang efektif dan efisien untuk menciptakan perilaku yang diperlukan guna menciptakan nilai yang superior bagi pembeli yang akhirnya akan berpengaruh pada kinerja bisnis secara berkelanjutan.

Hasil uji hipotesis ini terungkap bahwa orientasi pasar yang dilaksanakan oleh manajer bertujuan untuk (1) mempertahankan variasi permintaan dan penawaran pasar yang terjadi, (2) memperoleh informasi yang jelas tentang pelanggan/memahami kebutuhan dan nilai yang diharapkan pelanggan, (3) memahami kekuatan pesaing, baik pesaing saat ini maupun pesaing masa yang akan datang. Hal ini sejalan dengan (a) Varadarajan dan Jayachandran (1999) yang menyatakan bahwa orientasi pasar adalah seperangkat tindakan nyata yang memungkinkan perusahaan mempertahankan variasi permintaan dan penawaran pasar dan memberikan respon yang tepat terhadap berbagai perubahan yang terjadi, (b) Naver dan Slater (1990) bahwa orientasi pasar terdiri dari tiga komponen penting yaitu orientasi kepada pelanggan, orientasi kepada pesaing, dan koordinasi antar fungsi.

Terkait dengan pengaruh orientasi pasar terhadap kinerja manajer koperasi pengelola susu sapi perah di Jawa Timur didukung oleh hasil kajian Jaworski dan Kohli (1993) bahwa penghindaran terhadap risiko dan penekanan manajemen puncak terhadap orientasi pasar berpengaruh terhadap kinerja karyawan.

Dengan demikian dapat dimaknai bahwa karyawan yang telah melaksanakan orientasi pasar berarti telah mengimplementasikan konsep pemasaran dalam koperasi dengan baik dan melakukan aktivitas yang konsisten.

Demikian juga disampaikan Suwasono (2006) walaupun prospek persusuan menjanjikan namun konsep dan strategi kebijakan umum kaitannya dengan menyongsong peluang usaha persusuan yang lebih baik maka anggota koperasi susu diharapkan untuk lebih bekerja keras.

\section{Pengaruh Pembelajaran Organisasi terhadap Kinerja Unit Bisnis}


Tidak terdapat pengaruh yang signifikan pada pembelajaran organisasi terhadap kinerja unit bisnis pada koperasi pengelola susu sapi perah di Jawa Timur. Hal ini terjadi dimana faktor kekompakan dan peningkatan sinergi serta komunikasi yang lebih intensif antara koperasi pengelola susu sapi perah di Jawa Timur dengan pihak GKSI (Gabungan Koperasi Susu Indonesia) belum berjalan optimal terutama kaitannya dengan penetapan kebijakan dan aturan tata niaga susu segar (Suwasono, 2006).

Hasil uji hipotesis pembelajaran organisasi ini tidak sejalan dengan dengan (a) Schein (1996) bahwa di dalam organisasi yang berorientasi pembelajaran organisasi akan terjadi proses pengembangan kemampuan yang dilakukan secara terus menerus guna menciptakan kinerja dan masa depan yang lebih baik, (b) Therin (2002) menyatakan bahwa pembelajaran organisasi mempunyai hubungan positif dengan kinerja finansial.

Demikian juga disampaikan oleh Suwasono (2006) yaitu menghimbau anggota koperasi susu di Jawa Timur untuk lebih kompak dan meningkatkan sinergi serta komunikasi yang intensif terutama pada induk koperasi susu GKSI Jawa Timur.

\section{Pengaruh Kepuasan Kerja terhadap Kinerja Unit Bisnis}

Tidak terdapat pengaruh yang signifikan pada kepuasan kerja terhadap kinerja unit bisnis pada koperasi pengelola susu sapi perah di Jawa Timur. Hal ini terjadi kaitannya dengan pengharmonisan peran organisasi koperasi (peran pengurus dan manajer) yang perlu dimaksimalkan terutama mengenai kedudukan, wewenang, dan tanggung jawab masing-masing (manajer dan pengurus) sehingga diharapkan terciptanya kenyamanan dan kepuasan kerja yang akan berdampak pada kinerja unit bisnis pada koperasi pengelola susu sapi perah di Jawa Timur (Nirbito, 2003).

Hasil uji hipotesis kepuasan kerja ini tidak sejalan dengan Churchill et al. (1985) bahwa kepuasan kerja mempunyai hubungan dengan kinerja manajer/karyawan dalam hubungannya dengan penjualan.

Selanjutnya disampaikan oleh Suwasono (2006) dimana pengharmonisan peran anggota organisasi koperasi (pengurus dan manajer) dalam usaha persusuan antar anggota koperasi GKSI Jawa Timur untuk lebih dioptimalkan. 


\section{Pengaruh Orientasi Pasar terhadap Kinerja Unit Bisnis}

Tidak terdapat pengaruh yang signifikan pada orientasi pasar terhadap kinerja unit bisnis pada koperasi pengelola susu sapi perah di Jawa Timur. Hal ini terjadi di samping faktor manajemen dan nakalnya pengurus koperasi, juga kurangnya perhatian pemerintah terhadap kebijakan pemerataan pemasaran dan pengkonsumsian susu sapi perah pada masyarakat di Jawa Timur dan juga pada wilayah yang lebih luas bahkan di pasar dunia (Mubardjo, 2006).

Hasil uji hipotesis orientasi pasar ini tidak sejalan dengan (a) Naver dan Slater (1990) bahwa orientasi pasar merupakan filosofi bisnis yang dipandang efektif dan efisien untuk menciptakan perilaku yang diperlukan guna menciptakan nilai yang superior bagi pembeli yang akhirnya akan berpengaruh pada kinerja bisnis secara berkelanjutan, (b) Deshpande et al (1993); Jaworski dan Kohli (1993) mengatakan bahwa hasil riset menunjukkan orientasi pasar akan meningkatkan kinerja bisnis, (c) Slater dan Naver (1994) menunjukkan bahwa orientasi pasar berpengaruh terhadap return on assets, penjualan, dan keberhasilan produk baru.

Demikian Mubarjo (2006) mengatakan bahwa hambatan-hambatan dalam pemasaran susu sapi perah di Jawa Timur disamping karena faktor manajemen, juga kurangnya perhatian pemerintah terhadap perkembangan gerakan koperasi khususnya koperasi pengelolaan susu perah di Jawa Timur.

\section{Pengaruh Kinerja Manajer terhadap Kinerja Unit Bisnis}

Tidak terdapat pengaruh yang signifikan pada kinerja manajer terhadap kinerja unit bisnis pada koperasi pengelola susu sapi perah di Jawa Timur. Hal ini terjadi dimana pada kenyataannya keserasian dan profesionalisme hubungan pengurus dengan manajer pada koperasi pengelola susu sapi perah di Jawa Timur belum tercipta bahkan masih bersifat problematik. Harapan-harapan sehubungan dengan pengangkatan manajer cenderung belum sepenuhnya dapat terpenuhi dalam memecahkan masalah manajemen, bahkan tidak jarang pengangkatan manajer mengundang dilema. Pengurus tidak menciptakan iklim yang kondusif dari pola sikap, pikir, dan tindakannya, demikian juga manajer 
tidak menanggapi secara positif dan proaktif yang dilihat dari sikap, pikir dan tindakannya (Nirbito, 2003).

Hasil uji hipotesis kinerja manajer ini tidak sejalan dengan (a) Rue dan Byars (1997) bahwa kinerja bisnis pada hakikatnya merupakan prestasi yang dicapai oleh suatu organisasi bisnis yang dapat dilihat dari hasil kinerja manajer, (b) Anonim (2000) bahwa produktivitas tenaga kerja (kinerja manajer) berpengaruh signifikan dengan tingkat pertumbuhan ekspor (kinerja bisnis). Dan sejalan dengan Nirbito (2003) dimana pada kenyataannya keserasian dan profesionalisme hubungan pengurus dengan manajer pada koperasi pengelola susu sapi perah di Jawa Timur belum tercipta bahkan masih bersifat problematik dan mengundang dilema.

Jadi dalam penelitian ini pembelajaran organisasi, kepuasan kerja, orientasi pasar, dan kinerja manajer tidak berpengaruh signifikan terhadap kinerja unit bisnis. Fenomena ini terjadi sesuai dengan data yang diperoleh di lapangan dari indikator-indikator yang diberikan untuk mengukur pembelajaran organisasi, kepuasan kerja, orientasi pasar, dan kinerja manajer pada koperasi pengelola susu sapi perah di Jawa Timur.

Demikian pula Suwasono (2006) mengatakan bahwa fungsi koordinasi terutama dalam mengharmoniskan peran pengurus dan manajer antar koperasi anggota GKSI Jawa Timur untuk lebih dimaksimalkan lagi.

Selanjutnya dikatakan oleh Nirbito (2003) dimana terjadinya ketidakharmonisan antara manajer dan pengurus juga dapat disebabkan oleh adanya pemberian pendidikan dan pelatihan yang tidak simultan, dimana selama ini walaupun telah banyak diselenggarakan pendidikan dan pelatihan untuk sumber daya manusia koperasi oleh berbagai lembaga atau instansi terkait namun penanganan pendidikan dan pelatihan untuk sumber daya manusia koperasi tersebut belum bertolak atas kesatuan pola program pendidikan dan pelatihan yang seharusnya diberikan karenanya efisiensi dan efektivitasnya dari penanganan pendidikan dan pelatihan untuk sumber daya manusia koperasi patut dipertanyakan.

Belum terciptanya keserasian hubungan manajer dengan pengurus dapat juga disebabkan adanya kemungkinan kesenjangan identifikasi manajer dan pengurus terutama dalam hal lamanya bekerja dan pendidikan yang diperoleh, 
dimana rata-rata lama bekerja para manajer koperasi pengelola susu sapi perah di Jawa Timur adalah 15 tahun dengan pendidikan sebagian besar sarjana adalah 21 orang dari 33 manajer dengan usia rata-rata 45 tahun dan seluruhnya status menikah (data di Lampiran 12). Sedangkan untuk pengurus koperasi pengelola susu sapi perah di Jawa Timur rata-rata lama bekerja 13 tahun tingkat pendidikan sarjana yang hampir berimbang jumlahnya dengan yang berpendidikan SMU yaitu 13 orang sarjana dan 12 orang SMU dengan usia ratarata 48 tahun dan berstatus menikah (data di Lampiran 13). Melihat kenyataan tersebut (terutama lama bekerja dan tingkat pendidikan) bagi manajer dan pengurus maka jarang terjadi kesenjangan yang dilihat dari pola sikap, pikir dan tindakannya, dimana ada kecenderungan pengurus tidak menciptakan iklim yang kondusif karena menganggap dirinya secara organisatoris adalah atasan manajer yang akibatnya manajer tidak menanggapi secara positif dan proaktif karena menganggap dirinya mempunyai kemampuan (pendidikan yang ratarata lebih tinggi dari pengurus).

\section{Kesimpulan}

Berdasarkan pada rumusan masalah dan tujuan penelitian, serta hasil penelitian dan pembahasan yang telah dilakukan pada bab-bab terdahulu, maka dapat ditarik kesimpulan sebagai berikut:

1. Pembelajaran organisasi yang dilaksanakan oleh koperasi pengelola susu sapi perah di Jawa Timur dapat meningkatkan kinerja manajer, akan tetapi peningkatannya tidak berpengaruh signifikan secara statistik.

2. Kepuasan kerja yang dilaksanakan oleh koperasi pengelola susu sapi perah di Jawa Timur dapat meningkatkan kinerja manajer, akan tetapi peningkatannya juga tidak berpengaruh signifikan secara statistik.

3. Orientasi Pasar yang dilaksanakan oleh koperasi pengelola susu sapi perah di Jawa Timur dapat meningkatkan kinerja manajer, sehingga dapat dikatakan berpengaruh signifikan terhadap kinerja manajer.

4. Pembelajaran organisasi yang dilaksanakan oleh koperasi pengelola susu sapi perah di Jawa Timur dapat meningkatkan kinerja unit bisnis akan tetapi peningkatannya tidak berpengaruh signifikan secara statistik. 
5. Kepuasan kerja yang dilaksanakan oleh koperasi pengelola susu sapi perah di Jawa Timur dapat meningkatkan kinerja unit bisnis, akan tetapi peningkatannya juga tidak berpengaruh signifikan secara statistik.

6. Orientasi pasar yang dilaksanakan oleh pengelola susu sapi perah di Jawa Timur juga dapat meningkatkan kinerja unit bisnis, akan tetapi peningkatannya tidak berpengaruh signifikan secara statistik.

7. Kinerja manajer yang dilaksanakan oleh koperasi pengelola susu sapi perah di Jawa Timur dapat menurunkan kinerja unit bisnis. Hal ini ditunjukkan dengan adanya kecenderungan-kecenderungan penurunan tingkat penjualan pada koperasi pengelola susu sapi perah di Jawa Timur, sedangkan kinerja manajer yang dilakukan relatif sangat baik.

\section{Saran-saran}

Untuk lebih meningkatkan kinerja unit bisnis, maka koperasi disarankan:

a) Meningkatkan pembelajaran organisasi yang mengarah pada

1) mengembangkan, baik pembelajaran individual maupun kolektif,

2) adaptif terhadap lingkungan eksternalnya,

3) menggunakan hasil pembelajarannya untuk mencapai hasil yang terbaik;

4) secara terus menerus menunjang kemampuan untuk berubah.

b) Memberikan kepuasan kerja yang lebih mengarah pada pemberian pekerjaan yang sesuai dan gaji yang pantas;

c) Meningkatkan orientasi pasar dengan lebih meningkatkan variasi permintaan dan penawaran pasar; dan

d) Memilih manajer yang benar-benar kompeten. 


\section{DAFTAR RUJUKAN}

Anonim. 2000. A Report For Trade Partner United Kingdom. Journal of Exporting and Business Performances.

Baker, W. Sinkula, J., 1999. The Synergestic Effect of Market Orientation and Learning Orientation on Organizational Performance, Journal of the Academy of Marketing Science, Vol. 27.

Churcill, Gilbert A., Neil M. Ford, Steven W. Hartley, and Orville C. Walter. Jr. 1985. The Determinants of Salesperson Performance: A Meta-Analysis. Journal of Marketing Research, 22 (May).

Garvin, D.A., 1993. Building a Learning Organization., Havard Business Review, JulyAgustust.

Horn, S., Chen, A.C., 1998. Market Orientation of Small and Medium Sized Firm in Taiwan, Journal of Small Business Management, Vol. 36.

Kohli, A.K., Jawarski, B.J., 1990. Market Orientation: The Construct, Research Propositions and Management Implication, Journal of Marketing, Vol. 54.

Locke, E.A., and G.P. Lutham. 1990. Work Motivation and Satisfacion: Light at the End of the Tunnel. Psychological Science.

Luthans, Fred, 1995. Organizational Behavior. Sevent Edition. New York: Mc. Graw-Hill.

Menon, A., Jaworski, B.J., Kholi, A.K., 1997, Product Quality: Impact of Interdepartmental Interaction, Journal of The Academy of Marketing Science, Vol. 25.

Naver, J.C., Slater, S.F., 1990. The Effect of a Market Orientation on Business Profitablity, Journal of Marketing, Vol. 54.

Pelham A.M., Wilson, D.T., 1996. A Longitudinal Study of the Impact of Market Structure, Firm Structure, Strategy and Market Orientation Culture on 
Dimensons of Small-Firm Performance, Journal of the Academy of Marketing Science, Vol 24.

Prawirokusumo, S., 2001. Ekonomi Rakyat, (Konsep, Kebijakan dan Strategi). Yogyakarta: BPFE.

Schneider, B. 1990. Alternative Strategies for Creating Service-oriented Organizations, in Service Management Effectiveness (D. Brown et. al) Jossey-Bass.

Schwab, D.P. dan L.L. Cunmings, 1970. Theories of Performance and Satisfaction. Industrial Relations.

Sinkula, J.M., 1994. Market Information Processing and Organizational Learning, Journal of Marketing, Vol. 58.

Sinkula, J.M., Baker, W.E., Noordewier, T., 1997. A Framework for Market-Based Organizational Learning: Lingking Values, Knowledge and Behavior, Journal of the Academy Marketing Science, Vol. 25.

Slater, S.F., Narver, J.C., 1995. Market Orientation and the Learning Organizational, Journal of Marketing, Vol. 59.

Voss, G.B., Voss, Z.G., 2000. Strategic Orientation and Firm Performance in An Artistic Environement, Journal of Marketing, Vol. 64.

Wiley and Sons, 1998. Organizational Behaviour, An Asia Pasific Perspective, Jacaranda Wiley Ltd: Australian.

*) Dr. Salim Al Idrus, MM., M.Ag, Dosen Fakultas Ekonomi UIN Malang 